\title{
Indoor production of loose-leaf lettuce (Lactuca sativa L.) using artificial lights and cooling system in tropical lowland
}

\author{
Mary Grace Semilla ${ }^{1, *}$, Ireneo Agulto ${ }^{2}$, Armando Espino $\mathrm{Jr}^{2}$, and Emmanuel Sicat $^{2}$ \\ ${ }^{1}$ Graduate Student, and ${ }^{2}$ Faculty, Department of Agricultural and Biosystems Engineering, College of Engineering, Central Luzon State \\ University, Science City of Muñoz, Nueva Ecija, Philippines
}

\begin{abstract}
In the Philippines, crop production hindrances are climate change effects, typhoon occurrences, seasonal dependent cropping pattern and decreasing farm areas. There is a need to strategize farming technologies. Controlled environment agriculture (CEA) has potential in addressing these issues. A farming set-up in controlled environment was developed using locally available materials, light emitting diodes (LED) as sole-source of light and cooling system for temperature manipulation. This study was conducted to benchmark temperature and light intensity requirements for growing loose-leaf lettuce in lowland tropics. Light intensities of 50, 100 and $150 \mu \mathrm{mol} \mathrm{m} \mathrm{m}^{-2} \mathrm{~s}^{-1}$ were tested under temperature settings of $25^{\circ} \mathrm{C}$ and $18^{\circ} \mathrm{C}$. Carbon dioxide and relative humidity were maintained at recommended levels. In actual chamber condition, average day/night temperatures inside were $25.3 \pm 0.4 / 25.5 \pm 0.2^{\circ} \mathrm{C}$ and $18.9 \pm 0.6 / 18.7 \pm 0.3^{\circ} \mathrm{C}$, for the first and second cycles, respectively, whereas, day/night temperatures outside chambers were $29.6 \pm 2 / 25.9 \pm 0.5$ and $26.2 \pm 1 / 23.6 \pm 0.6$ during the first and second cycles, respectively. Under two temperature settings, best yield per unit area was observed at required light intensity of $150 \mu \mathrm{mol}$ $\mathrm{m}^{-2} \mathrm{~s}^{-1}$. No significant difference in productivity was observed under $25^{\circ} \mathrm{C}$ and $18^{\circ} \mathrm{C}$. Also, no significant difference in productivity was observed between plants in two temperature settings and plants outside.
\end{abstract}

\section{Introduction}

Controlled environment agriculture (CEA), the cultivation of plants in enclosed environment in which growth factors are carefully controlled and programmed [1] has become a trend, especially in developed countries. CEA has been done both in completely indoor setting and greenhouse [2]. Commercial crop production and researches are conducted under environmentally controlled spaces [3] in which abiotic factors such as light, water carbon dioxide, temperature and management options like planting material and fertilizer application are manipulated [4].

In the Philippines, greenhouse has been adapted both in upland [5] and lowland [6]. However, initiatives are still done to encourage production in greenhouse than in open field [7]. The frequent occurrence of typhoon decreases production [8] and might as well threatens to destroy greenhouse structures. Moreover, production in the country is seasonal dependent. In a tropical lowland setting, greenhouse problems still arise due to temperature rise inside the structure $[6,9]$, thus the need to control environment favourable for crops. Indoor farming offers a lot of potentials in terms of food sustainability [10] and increased productivity, as crops can be planted all-year round. With this system, plants can be more resilient to typhoons and climate change effects such as flood or drought. This study was conducted to benchmark temperature and light intensity for loose-leaf lettuce as test crop.

\section{Methodology}

Three chambers were constructed using locally available materials with each having floor area of $2.5 \mathrm{~m} \times 6.0 \mathrm{~m}$ and ceiling height of $2.5 \mathrm{~m}$. Each chamber was equipped with two $1 \mathrm{hp}$ window-type air-conditioning units (AC) operated alternately for 12 hours, two 70-watt circulating fans, and two sprinkler foggers (Figure 1). Plants were provided with 150,100 and $50 \mu \mathrm{mol} \mathrm{m}^{-2} \mathrm{~s}^{-1}$ photosynthetic photon flux (PPF), for 14 hours. ECOLUM LED T8 tube lights, $6500 \mathrm{~K}$ daylight were used such that 4,3 and 2 tubes would provide PPF of $150\left(\mathrm{~L}_{3}\right), 100\left(\mathrm{~L}_{2}\right)$ and $50\left(\mathrm{~L}_{1}\right)$, respectively. Also, planting bench with dimension of $1 \mathrm{~m} \times 5 \mathrm{~m} \times 0.8 \mathrm{~m}$ was installed in each chamber. Planting pots $(20 \mathrm{~cm} \times 20 \mathrm{~cm} x$ $14 \mathrm{~cm}$ ) containing $1800 \mathrm{~g}$ substrate mixture with $1: 1: 1$ ratio by volume of garden compost, carbonized rice hull and vermicast, added with $2000 \mathrm{~mL}$ water was planted with two 15 days old fanfare (grand rapid or green ice) lettuce. Plants were grown in three rows along length of planting bench and harvested at 24 days after transplanting (Figure 2). Lettuce plants were also grown outside the chamber for comparison.

* Corresponding author: mgnsemilla@gmail.com 


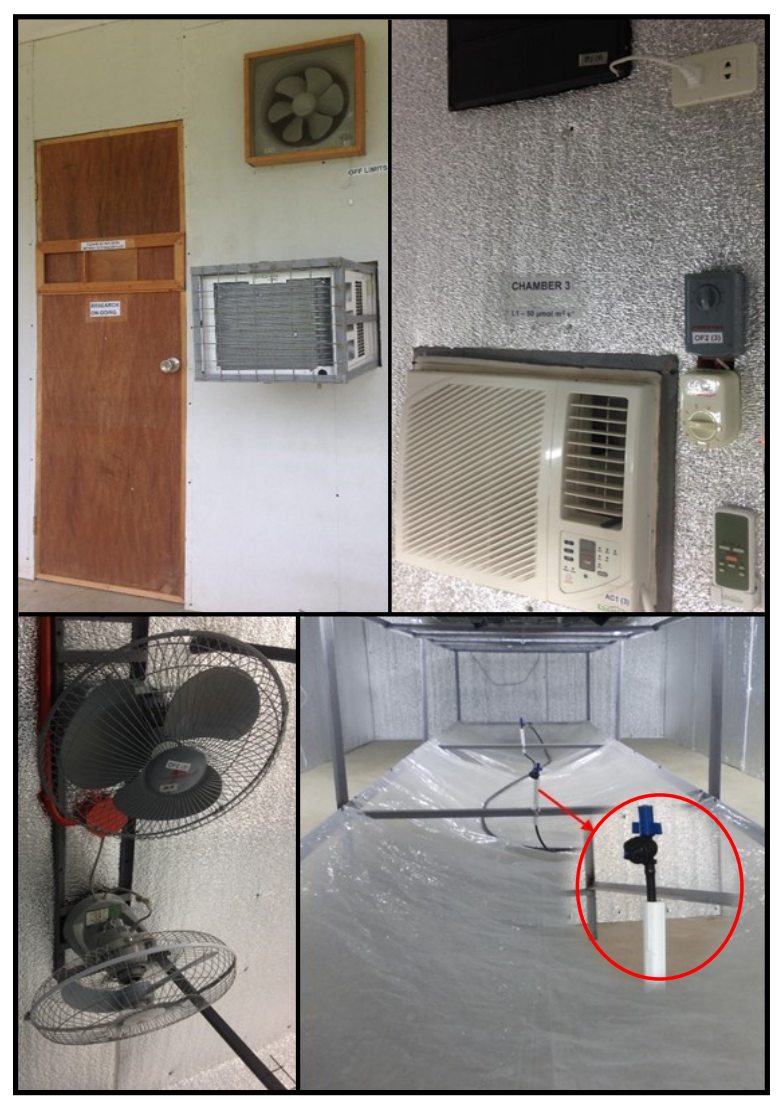

Figure 1. Components of the constructed CEA system

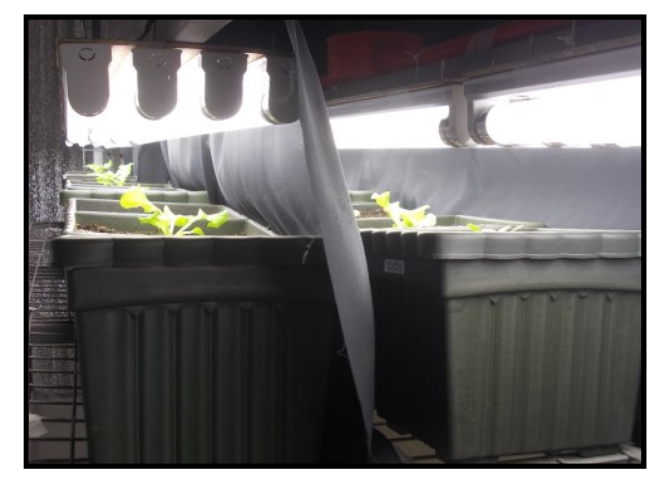

Figure 2. Plants grown in rows under LED T8 daylight

Temperatures of $25^{\circ} \mathrm{C}\left(\mathrm{T}_{1}\right.$, first cycle $)$ and $18{ }^{\circ} \mathrm{C}\left(\mathrm{T}_{2}\right.$, second cycle) were tested using the air-condition system. Carbon dioxide $\left(\mathrm{CO}_{2}\right)$, temperature and relative humidity (RH) were monitored using Desktop $\mathrm{CO}_{2}$ Monitor 7788 Green Day Model by AZ Instruments Corp., Taiwan. PPF levels in each chamber were also monitored using Handheld Quantum Meter with integral sensor MQ-100 Model by Apogee Instruments Inc., USA.

\subsection{Pre-test operation}

Temperature and light distributions were evaluated prior to crop establishment. Without the plants inside the chambers, cooling system was operated to check the temperature distribution. Temperature was measured in 40 locations within the planting bench. On the other hand, light distribution was assessed by measuring the light intensity below the lighting fixture with the sensor at soil level approximately $13 \mathrm{~cm}$ from the LED tubes.

Three frequencies of monitoring environmental parameters such as temperature, $\mathrm{CO}_{2}$ and $\mathrm{RH}$ were put to trial; hourly, every two hours and five measurements in a day or within 24 hours.

\subsection{Monitoring of environmental parameters}

\subsubsection{Light intensity}

Monitoring light intensities were done daily, one hour before lights on and one hour after lights off. Measurement was done by positioning the sensor at canopy level just below the lighting fixture [11-12]. As observed, the PPF value changed over time especially when the crop grows. Thus, to maintain PPF values of 50,100 and 150, the height of the lighting fixtures were adjusted; a technique employed in other studies [13-15].

\subsubsection{Temperature, $\mathrm{CO}_{2}$ and $\mathrm{RH}$}

During crop establishment, temperature, $\mathrm{CO}_{2}$ and $\mathrm{RH}$ were monitored daily at daytime (lights on) and nighttime (lights off).

Hourly monitoring was necessary to monitor RH and to operate foggers, if its value reached $50 \%$. During pretest operation (hourly), no significant differences in temperature, $\mathrm{CO}_{2}$ and $\mathrm{RH}$ were observed from 9:00 pm to 5:00 am. This was the night time condition. To acquire representative data for night condition, measurements were taken at 5:00am and at 9:00pm. Daytime measurements were taken hourly from 6:00 am to $8: 00 \mathrm{pm}$. This monitoring schedule was based on the results of the pre-test operations.

\section{Results and Discussion}

\subsection{Temperature and light Distribution}

Temperature was found evenly distributed within the chamber. Also, light intensities of lighting fixture in each chamber were found with no significant differences between plant rows.

\subsection{Environmental parameters in the chamber}

\subsubsection{Light intensity}

Light intensities were within the range required for the treatments (Figures 3 and 4). There were fluctuations in average daily PPF because light intensity at canopy level was influenced by lettuce's growth. As leaves reached closer to the light source, PPF readings became higher. Adjustment of the height of lighting fixtures (about $5 \mathrm{~cm}$ higher) then caused lower light intensity readings. PPF trend of $L_{3}$ varies from $L_{2}$ and $L_{1}$. For the first cycle, this occurred at 11-14 days, while for the second cycle at 


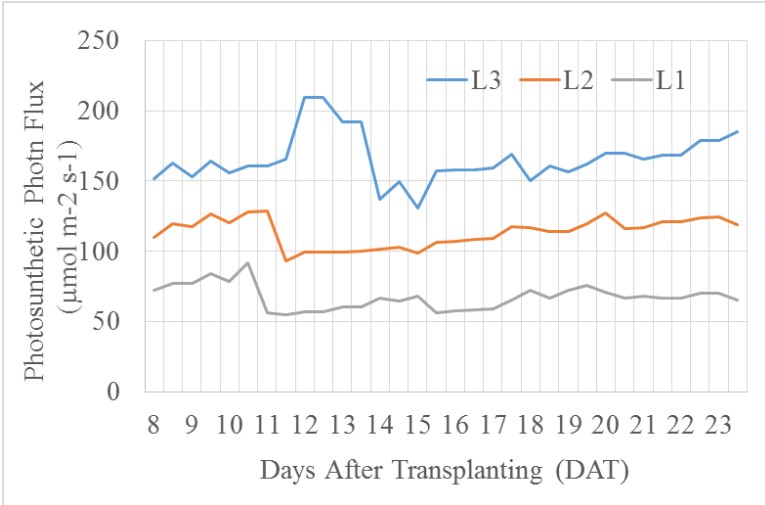

Figure 3. Average daily PPF measured at first cycle $\left(25^{\circ} \mathrm{C}\right)$

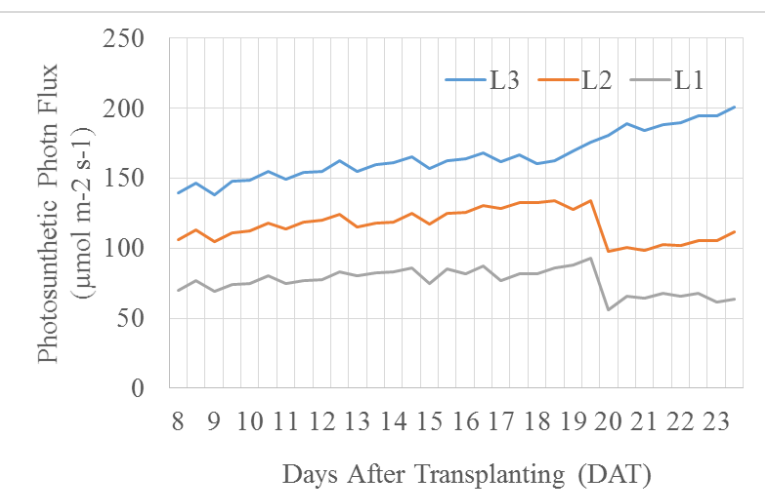

Figure 4. Average daily PPF measured at second cycle $\left(18^{\circ} \mathrm{C}\right)$

21-23 days. The disparity was influenced by the difference in plant height response (data not shown) under $25{ }^{\circ} \mathrm{C}$ and $18{ }^{\circ} \mathrm{C}$. Thus, the adjustment time of lighting fixtures also varies. Also, light intensity in chamber changes over time in a day even with the light sensor placed at same location [16].

\subsubsection{Temperature, $\mathrm{CO}_{2}$ and $\mathrm{RH}$}

Figures 5 and 6 show the actual day and night temperatures inside the chambers with the AC thermostat settings of $25^{\circ} \mathrm{C}$ and $18{ }^{\circ} \mathrm{C}$. In both settings, the current system achieved the required temperature treatments. Also, $\mathrm{CO}_{2}$ and $\mathrm{RH}$ were maintained at levels required for normal plant growth.

Temperature is important since it controls the rate of plant growth [17], its physiological and chemical processes [17-18]. During first cycle, average day and night temperatures within chambers were $25.3 \pm 0.4{ }^{\circ} \mathrm{C}$ and $25.5 \pm 0.2{ }^{\circ} \mathrm{C}$, respectively. Chamber temperatures during second cycle planting were $18.9 \pm 0.6^{\circ} \mathrm{C}$ during day and $18.7 \pm 0.3{ }^{\circ} \mathrm{C}$ during night. Day and night temperatures outside the chambers were $29.6 \pm 2 / 25.9 \pm 0.5$ and $26.2 \pm 1 / 23.6 \pm 0.6$ during the first and second cycles, respectively.

Carbon dioxide $\left(\mathrm{CO}_{2}\right)$ levels were within acceptable range of $380 \mathrm{ppm}$ [19] to $1500 \mathrm{ppm}$ [20] and recommended levels of 800-1200 ppm [3]. Average day and night $\mathrm{CO}_{2}$ inside the chambers were $496.1 \pm 22$ and

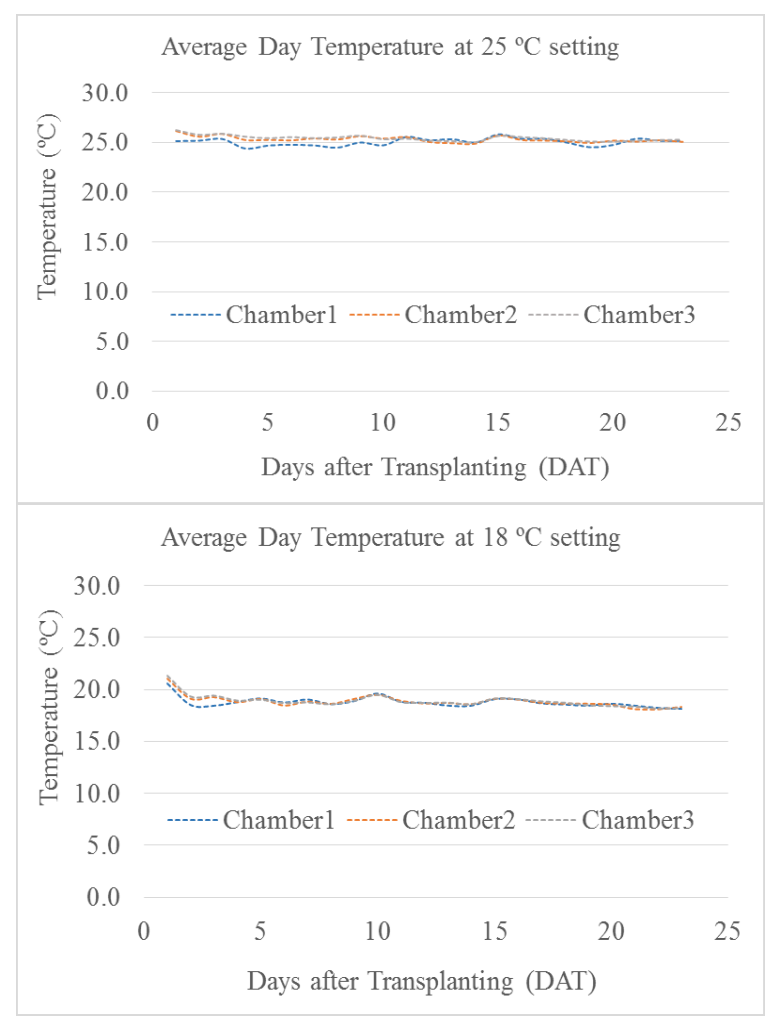

Figure 5. Day temperature at $25^{\circ} \mathrm{C}$ and $18^{\circ} \mathrm{C}$ setting

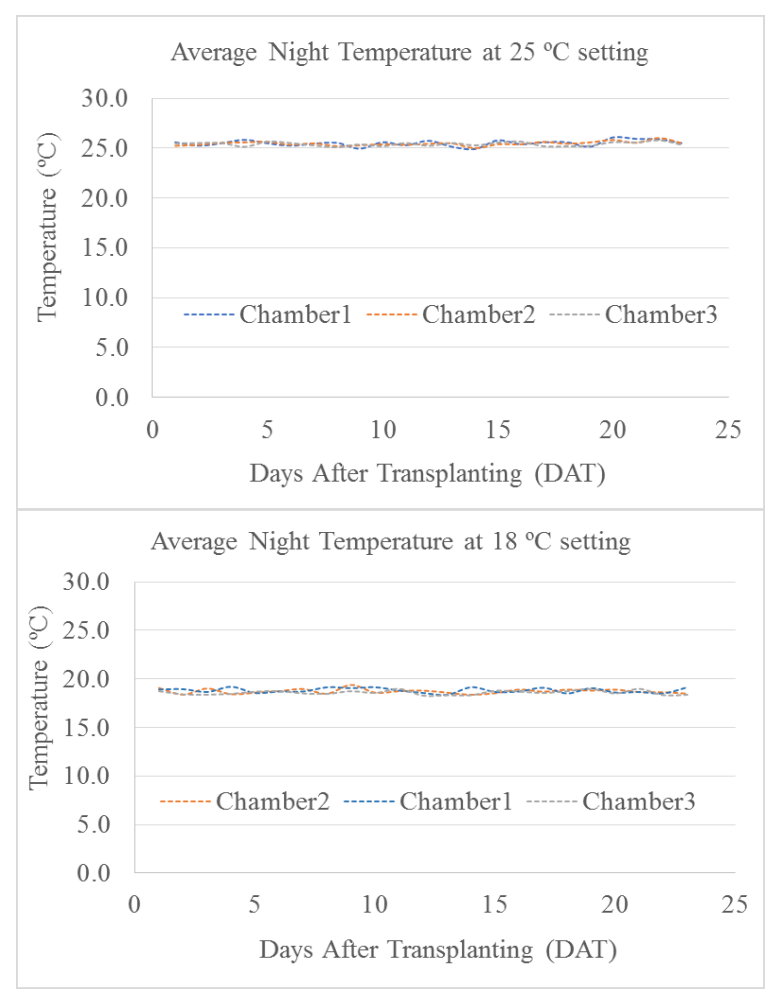

Figure 6. Night temperature at $25^{\circ} \mathrm{C}$ and $18{ }^{\circ} \mathrm{C}$ setting

$520.2 \pm 37$ ppm, respectively, during first cycle, and $463.7 \pm 35 \mathrm{ppm}$ and $464.2 \pm 34 \mathrm{ppm}$, respectively during second cycle. Other researches had maintained $\mathrm{CO}_{2}$ levels close to what were observed [21-23]. Thus, required $\mathrm{CO}_{2}$ for plant's normal growth was achieved. 
Relative humidity $(\mathrm{RH})$ in the chambers was maintained according to acceptable RH of $40-80 \%$ [3] avoiding water stress, since RH affects plant water take up [3] and transpiration rate [17]. Average day and night $\mathrm{RH}$ within chambers were $65.8 \pm 4$ and $80.3 \pm 3 \%$, respectively, during first cycle, and $62.5 \pm 5$ and $75.6 \pm 5 \%$, respectively, during second cycle. Thus, relative humidity within chambers was sufficient enough for plant to perform normal physiological processes.

\subsection{Yield performance of loose-leaf lettuce}

On the average, yield of fanfare lettuce reached 29.6 grams per plant covering a planting density of about 14 plants per square meter. With the system, area productivity (grams of lettuce per square meter planted) was best under highest light intensity of $150 \mu \mathrm{mol} \mathrm{m}^{-2} \mathrm{~s}^{-1}$ at both temperature settings (Table 1). Analysis of variance in $\mathrm{CRD}$ showed that at $25^{\circ} \mathrm{C}, \mathrm{L}_{3}$ with area productivity of 400.79 grams of lettuce harvested per square meter was significantly higher than those under treatments $\mathrm{L}_{2}$ and $\mathrm{L}_{1}$. Similarly, at $18{ }^{\circ} \mathrm{C}, \mathrm{L}_{3}$ with area productivity of $423.02 \mathrm{~g} \mathrm{~m}^{-2}$, was significantly higher than those under $\mathrm{L}_{2}$ and $\mathrm{L}_{1}$. These results were comparable to other study where fresh weight of lettuce significantly increased at higher light intensity [24]. Using T-test (data not shown), no significant difference was found on the area productivity of lettuce at $18{ }^{\circ} \mathrm{C}$ and $25{ }^{\circ} \mathrm{C}$ temperature setting. Also, productivity of lettuce inside the chambers, at both temperature setting, were not significantly different from those outside the chambers with area productivity of $316.67 \mathrm{~g} \mathrm{~m}^{-2}$.

Table 1. Area productivity $\left(\mathrm{g} \mathrm{m}^{-2}\right)$ of loose-leaf lettuce

\begin{tabular}{|c|c|c|}
\hline 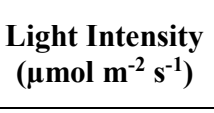 & $\begin{array}{c}\text { First Cycle, } \\
\mathrm{T}_{1}\left(25^{\circ} \mathrm{C}\right)\end{array}$ & $\begin{array}{c}\text { Second } \\
\text { Cycle, } \mathrm{T}_{2} \\
\left(18^{\circ} \mathrm{C}\right) \\
\end{array}$ \\
\hline $50\left(\mathrm{~L}_{1}\right)$ & $102.38 \pm 26^{\mathrm{c}}$ & $126.99 \pm 44^{\mathrm{c}}$ \\
\hline $100\left(\mathrm{~L}_{2}\right)$ & $284.92 \pm 71^{b}$ & $257.14 \pm 56^{\mathrm{b}}$ \\
\hline $150\left(\mathrm{~L}_{3}\right)$ & $400.79 \pm 95^{\text {a }}$ & $423.02 \pm 113^{\mathrm{a}}$ \\
\hline
\end{tabular}

Means of the same column with same letter are not significantly different by LSD at 95\% level of confidence

\section{Conclusions and Recommendation}

The constructed CEA system can maintain average temperature within the selected temperature settings of $18{ }^{\circ} \mathrm{C}$ and $25^{\circ} \mathrm{C}$. In conclusion, the system can produce loose-leaf lettuce at both temperature settings. However, it is highly recommended that the light intensity should be set at least $150 \mu \mathrm{mol} \mathrm{m} \mathrm{m}^{-2} \mathrm{~s}^{-1}$ for better crop performance. Also, improvement can be made on the lighting system. Although not included in the study, lettuce was found to be bitter at $25{ }^{\circ} \mathrm{C}$. Thus, temperature settings between $18{ }^{\circ} \mathrm{C}$ and $25{ }^{\circ} \mathrm{C}$ can be tested. As such, the maximum temperature setting that will give the lowest power consumption which will not produce bitter lettuce can be determined. Further studies on quality of lettuce, other lettuce varieties and other cultivars as test crops, are recommended.

\section{References}

1. L. Fogg, K. Rauhala, E. Satterfield, US Patent 889965 (1979)

2. L. Chin, K. Chong, Int. J. Phys. Sci. (2012)

3. ASHRAE, ASHRAE Fundamentals Handbook. Am. Soc. Agri. Eng. (2001)

4. T. Kozai, A. Sakaguchi, T. Akiyama, K. Oshima, K. Yamada. Presentation, Assoc. for Vert. Farm (2015)

5. J. Malamug, et.al., Tech. Rep. BSU, Phil (2011)

6. V. Ramos, MS Thesis, CLSU, Phil. (2008)

7. P. Armenia, K. Menz, G. Rogers, Z. Gonzaga, R. Gerona, E. Tausa, ACIAR-PCARDD S. Phil. Fruits and Veg. Prog. Meeting. Cebu, Phil. (2012)

8. F. Lansigan, W. de los Santos, J. Coladilla, Agric. Ecosys. \& Environ. 82, 1-3, 129-137 (2000)

9. M. Karlson, Univ. Alaska Fairbanks, U.S. Dept. of Agric. (2016)

10. K. Specht, R. Siebert, I. Hartmann, U. Freisinger, M. Sawicka, A. Werner, S. Thomaier, D. Henckel, H. Walk, A. Dierich, Agric. and Hum. Val. 31, 1, 33-51 (2014)

11. R. Curry, T. Kozlowski, R. Prince, T. Tibbits. Cont. Envi. Guid. Acad. Press Inc. (1979)

12. Crop Science Society, https://dl.sciencesocieties. org/ files/publications/ces-guide.pdf. (2002)

13. R. Wojciechowska, A. Kolton, M. Zupnik, O. Dlugosz-Grochowska, W. Grzesiak. Folia Hort., 25, 1 (2013)

14. G. Goins, N. Yorio, M. Sanwo, C. Brown, J. Exp. Bot. 48, 312 (1997)

15. C. Brown, J. Amer. Soc. Hort. Sci., 120, 5 (1995)

16. C. Cabacan, F. R. Cruz, I. Agulto, IEEE $9^{\text {th }}$ Int. Conf. on Hum. Nanotech. Info-Tech Com. and Contrl. Envi. and Mangmt. (2017)

17. M. Brechner, A. Both, Hydroponic Lettuce Handbook, http://www.cornellcea. com/resources Publications/growersHandbooks/lettuce.html.

18. H. Lorenz, H. Wiebe, J. Scienta, 13, (1980)

19. L. Xiaoying, G. Shirong, X. Zhigang, J. Xuelei, HortScience 46, 2 (2011)

20. H. Shimizu, Y. Saito, H. Nakashima, J. Miyasaka, K. Ohdoi, $18^{\text {th }}$ IFAC World Congress, (2011)

21. K. Cope, B. Bugbee, HortScience, 504-509 (2013)

22. G. Massa, T. Graham, T, Haire, C. Flemming, G. Newsham, R. Wheeler, HortScience, 50, 3, 501-506 (2015)

23. Z. Bian, R. Cheng, Q. Yang, J. Wang, J. Amer. Soc. Hort. Sci 141, 2, 186-195 (2016)

24. W. Fu, P. Li, Y. Wu, J. Scienta, 135 (2012) 